\title{
PENTINGNYA PELAYANAN KESEHATAN KEPADA NARAPIDANA MUDA DI LEMBAGA PEMASYARAKATAN
}

THE IMPORTANCE OF HEALTH SERVICES TO YOUTH IN CORRECTIONAL INSTITUTIONS

\author{
Benny Syahputra Damanik, Ali Muhammad, A.K.S.
}

Politeknik Ilmu Pemasyarakatan

bennydamanik0@gmail.com

alimuhammad32@gmail.com

\section{Info Artikel}

Sejarah Artikel :

Diterima 13 Nov 2021

Disetujui 19 Nov 2021

Publikasi November 2021

\section{Keyword:}

Young Prisoners, Health Promotion, Health Needs.

\section{Albstract}

Young prisoners' health needs represent a matter of constant importance for any prison administration. These are addressed through direct medical services, as well as through other activities of health promotion. If the medical services are provided by trained medical staff, health promotion is usually provided by non-medical staff, such as social workers, psychologists, educators etc. Also, because healthy behaviors are best promoted through social modeling, such activities require the involvement of all prison staff, including non-specialists such as guardians. Thus, for health promotion to be effective it needs to be approached by the whole prison staff, meaning that the medical and non-medical specialists, as well as other prison staff need to have a common understanding of young prisoners health needs and to work as a team. This can be done through prison staff training. The article addresses these issues by summarizing the Indonesia country reports of the project "Health Promotion for Young Prisoners" funded in the framework of the Public Health Program.

\section{Ahstrak}

Kebutuhan kesehatan narapidana muda merupakan hal yang selalu penting bagi administrasi penjara mana pun. Ini ditujukan melalui pelayanan medis langsung, serta melalui kegiatan promosi kesehatan lainnya. Jika layanan medis disediakan oleh tenaga medis terlatih, promosi kesehatan biasanya dilakukan oleh tenaga non medis, seperti pekerja sosial, psikolog, pendidik dll. Juga, karena perilaku sehat paling baik dipromosikan melalui model sosial, kegiatan semacam itu memerlukan keterlibatan semua staf pegawai penjara, termasuk non-spesialis seperti wali narapidana. Dengan demikian, agar promosi kesehatan menjadi efektif perlu didekati dengan: seluruh staf lapas, artinya para ahli medis dan non-medis, serta staf lapas lainnya perlu memiliki kesamaan pemahaman tentang kebutuhan kesehatan narapidana muda dan untuk bekerja sebagai sebuah tim. Hal ini dapat dilakukan melalui pelatihan staf penjara. Artikel mengatasi masalah ini dengan meringkas laporan negara kita tentang proyek "Promosi Kesehatan untuk Tahanan Muda" didanai dalam rangka Program Kesehatan Masyarakat. 


\section{A. PENDAhUluan}

Kondisi terbakarnya Lembaga Pemsyarakatan ${ }^{1}$ (LAPAS) Kelas 1 A Tanjung Gusta, Medan beberapa waktu yang lalu menambah panjang catatan persoalan yang terjadi di sekitar kehidupan LAPAS di Indonesia. Diantara permasalahan yang terjadi di LP adalah keributan antar sesama narapidana, perlakuakn para petugas LAPAS terhadap narapidana, pelarian narapidana, terjadinya pembunuhan sesam narapidana, perdagangan narkoba, pelecehan seksual dan berbagai persoalan-persoalan negatif lain yang sering terdengar dari balik jeruji besi tersebut. $^{2}$

Persoalan-persoalan tersebut di atas sering mewarnai kondisi kehidupan di berbagai LAPAS di mana saja lebih khusus di Indonesia. Beberapa deprivasi yang dialami narapidana selama menjalani masa pemidanaan di LAPAS serta adanya subkultur narapi dana merupakan penyebab timbulnya berbagai persoalan yang ada, misalnya proses prisosialisasi narapidana di LAPAS. Apabila pembicaraan diseputar narapidana dan LAPAS dalam melaksanaan tujuan pemidanaan, maka pembicaraan berbagai deprivasi yang dialami para narapidana, proses prisonisasi, maupun kegagalan proses sistem pemidanaan, khususnya pidana penjara yang masih berlangsung dan tetap ada di muka bumi ini. Setiap saat dan setiap waktu, selalu ada perubahan dan peristiwa di LAPAS. $^{3}$

Selanjutnya artikel ini mencoba menyajikan masalah LAPAS dari sisi yang berbeda, tetapi masih dalam koridor UndangUndang Nomor 12 Tahun 1995 tentang Pemasyarakatan, sebagaimana landasan filosifis dari undang-undang tersebut adalah "bahwa pada hakikatnya Warga Binaan Pemasyarakatan sebagai insan dan sumber

1 Istilah Lembaga Pemasyarakatan digunakan secara resmi sejak tanggal 27 April 1964 bersamaan dengan berubahnya sistem kepenjaraan menjadi sistem pemasyarakatan, Lihat Petrus Irwan Panjaitan dan Pandapotan Simorangkir, Lembaga Pemasyarakatan Dalam Prespektif Sistem Peradilan Pidana Penjara, ( Jakarta : Pustaka Sinar Harapan, 1995), hal 25

2 Rumadan, Ismail. "Problem Lembaga Pemasyarakatan di Indonesia dan Reorientasi Tujuan Pemidanaan." Jurnal Hukum dan Peradilan 2.2 (2013): 263-276.

DOI: http://dx.doi.org/10.25216/jhp.2.2.2013.263-276 3 Ibid daya manusia harus diperlakukan dengan baik dan manusiawi dalam satu sistem pembinaan yang terpadu". Oleh karenanya artikel ini akan focus pada segmen yang harus ditangani oleh administrasi penjara di Indonesia saat merencanakan pelatihan staf tentang kegiatan promosi kesehatan narapidana muda. Data statistik dari Administrasi Lembaga Pemasyarakatan menunjukkan bahwa narapidana muda mewakili $20 \%$ dari total populasi penjara pada tahun 2010. Menurut data yang sama, $61 \%$ berusia antara $21-24$ tahun, $31 \%$ antara 18-21 tahun dan 8\% antara 14-18 tahun. Hingga 2008, populasi narapidana muda mencatat tren penurunan, mirip dengan populasi penjara dewasa. Peningkatan ringan tercatat setelah 2008. Sebagian besar tindak pidana yang dilakukan oleh pemuda di Indonesia terdiri dari pencurian dan narkoba. Penggunaan narkoba di penjara juga umum di kalangan anak muda. Pada tahun 2008, menurut Badan Narkoba Nasional, sekitar $29 \%$ narapidana yang menyatakan memiliki riwayat penggunaan narkoba berusia hingga 24 tahun. Menurut HIV tahun 2009, Survei Perilaku HBV dan HCV di antara pengguna narkoba suntik (IDU) di Bukares dilaksanakan di bawah koordinasi pihak, 56\% Penasun (berusia antara 18-24 tahun, mantan narapidana dan dengan narkoba use history) menyatakan bahwa mereka menyuntik diri sendiri selama di penjara. Menurut HIV, HBV dan HCV , Survei Pengawasan Perilaku di antara tahanan di Indonesia dilaksanakan, data kelompok usia 18-24 tahun menunjukkan bahwa $9 \%$ menggunakan kokain; $6 \%$ disuntikkan dengan zat; $4 \%$ menerima / memiliki akses ke jarum / alat suntik steril gratis; $49 \%$ ditato di penjara; $22 \%$ menggunakan kondom selama hubungan terakhir mereka; 47\% menerima / memiliki akses gratis ke kondom; $53 \%$ menghadiri sesi tentang HIV/AIDS; 33\% dites HIV dalam hidup mereka.

Perawatan medis di penjara disediakan oleh jaringan medis penjara, yang termasuk dalam 40 perawatan primer kantor, 45 kantor gigi dan perawatan khusus lainnya, 10 laboratorium gigi, 40 apotek dan 6 rumah sakit penjara. Utama Masalah terus-menerus dari jaringan medis penjara Indonesia adalah defisit staf medis yang tinggi. Tujuan strategis ANP pada perawatan medis 
termasuk memastikan sumber daya yang dibutuhkan, mengembangkan program untuk pencegahan penyakit, pendidikan narapidana dan peningkatan kesehatan, serta peningkatan efisiensi kerja sama dengan sektor medis publik. Bidang utama yang menjadi fokus program medis penjara adalah pencegahan HIV, bahaya pengurangan antara penasun, pengendalian tuberkulosis dan kesehatan mental. ANP bekerja sama dengan berbagai internasional organisme dan dengan lembaga publik nasional dan organisasi non-pemerintah untuk meningkatkan dan mempromosikan perawatan medis di lingkungan penjara.

Proyek HPYP "Health Promotion for Young Prisoners" bertujuan untuk mengembangkan dan meningkatkan promosi kesehatan bagi kaum muda yang rentan di pengaturan penjara, berusia antara 14 dan 24 tahun. Ini secara khusus ditujukan untuk pelaksanaan kesehatan selanjutnya peralatan pendidikan promosi untuk tahanan muda untuk digunakan oleh staf penjara di seluruh Negara. Peralatan yang dimaksudkan untuk digunakan oleh berbagai kategori staf penjara dan membahas faktor-faktor terkait kesehatan mengenai penyakit menular, kesehatan seksual, kesehatan mental serta pencegahan dan pengobatan penggunaan narkoba. Peralatannya adalah hasil dari proses berorientasi penelitian yang mencakup penilaian kebutuhan di antara narapidana muda dan staf penjara, sebagai sekaligus sebagai tahap uji coba.

\section{B. METODE PENELITIAN}

Kerangka umum penelitian ini berupa penilaian kebutuhan kaum muda/remaja yang rentan di penjara, serta staf penjara dan perwakilan dari LSM yang mungkin menjadi pemberi promosi kesehatan di pengaturan penjara. Ini menggunakan metode umum untuk pengumpulan dan analisis data di semua negara mitra, dengan beberapa unsur-unsur tertentu tergantung pada ciri-ciri populasi yang termasuk dalam sampel dan jenis-jenisnya unit penahanan adalah data yang dikumpulkan. Berdasarkan hasil yang dihasilkan oleh masing-masing dari tujuh negara, perangkat untuk promosi kesehatan dikembangkan untuk penggunaan staf penjara bersama-sama dengan narapidana muda.
Yang kami maksud dengan promosi kesehatan adalah setiap kegiatan, program, dan inisiatif yang bertujuan untuk meningkatkan kesadaran dan mengembangkan keterampilan dalam mencegah dan meningkatkan kesehatan fisik, emosional, mental dan sosial individu dan kelompok dalam hak asuh. Ini mencakup berbagai aspek promosi kesehatan yang dapat ditangani dalam tahanan, bervariasi dari: olahraga reguler hingga sesi informatif untuk pelanggar muda tentang alkohol, tembakau, dan penggunaan narkoba, pelatihan yang benar kebersihan gigi / mulut, intervensi sehubungan dengan kebutuhan kesehatan mental, menyakiti diri sendiri dan bunuh diri hingga pelatihan konflik pengelolaan.

Populasi yang dianalisa di Indonesia termasuk tahanan muda berusia antara 14 dan 24 tahun, dalam tahanan atau dihukum. Populasi dari mana data dikumpulkan termasuk narapidana muda berusia antara 18 dan 24 tahun, staf penjara dan penyedia promosi kesehatan lainnya di lingkungan penjara. Data tidak dikumpulkan dari segmen tahanan muda berusia antara 14 dan 17 tahun, karena persetujuan orang tua tidak dapat dicapai. Absennya usia ini segmen dari sampel teoritis digantikan oleh staf penjara yang bekerja di pusat pendidikan ulang.

Berbeda metode yang digunakan: kuesioner dengan narapidana muda, staf penjara dan anggota LSM, kelompok fokus dengan orang-orang muda di lingkungan penjara dan wawancara dengan staf penjara dan anggota LSM.

Untuk penerapan kuesioner dengan tahanan muda, sampel teoritis 100 subjek dikembangkan berdasarkan struktur populasi penjara umum. Sampel dibagi menjadi tiga lapisan: usia tahanan, jenis unit (untuk anak di bawah umur \& remaja atau untuk orang dewasa) dan jenis penahanan (penahanan atau hukuman). sampel termasuk 3 tahanan wanita, berusia 20, 21 dan 23 tahun, menjalani hukuman mereka di penjara untuk wanita. Sisanya 97 narapidana adalah lakilaki. Seperti disebutkan sebelumnya, kelompok fokus dengan tahanan muda juga diorganisir. mata pelajaran dipilih di antara tahanan yang awalnya menyelesaikan kuesioner, atas dasar sukarela. 3 fokuskelompok diorganisir di unit penahanan yang 
berbeda, untuk menangkap sebanyak mungkin organisasi perbedaan. Jadi, satu kelompok fokus dibuat di penjara untuk orang dewasa (berusia di atas 22 tahun), satu lagi di penjara penjara dan yang ketiga di penjara untuk anak di bawah umur \& remaja (berusia antara 14 dan 21 tahun). Rata-rata 9 peserta per kelompok fokus setuju untuk berpartisipasi. Staf Lapas dan anggota LSM yang menjawab kuesioner dan/atau berpartisipasi dalam wawancara dipilih menggunakan kriteria ketersediaan, artinya orang-orang tersebut berada di lokasi pada saat pengumpulan data dan mereka bersedia untuk berpartisipasi. Kriteria pemilihan sampel lainnya termasuk mereka profesi dan pengalaman mereka dalam bekerja dengan narapidana muda, 41 kuesioner diterapkan dan 12 wawancara diambil dengan staf penjara dan anggota LSM.

\section{PEMBahasan}

Kesehatan dipandang sebagai konsep ganda dalam representasi narapidana muda itu berarti baik fisik dan mental kesejahteraan. Orang yang sehat dipandang memiliki fisik yang fit, memiliki tubuh yang serasi dan mampu berekspresi perasaan positif. Aspek fisik kesehatan diberikan kepentingan tertinggi, terutama yang terlihat kehadiran suatu penyakit dikenali oleh gejalagejala yang dapat dirasakan. Meskipun aspek kesehatan mental dan emosional ditempatkan pada tingkat sekunder, mereka mudah disebutkan. Tahanan muda sadar bahwa tubuh dan pikiran terhubung dan bahwa keadaan yang satu mempengaruhi yang lain. Tahanan muda juga mengasosiasikan kesehatan dengan manusia tindakan (kesejahteraan seseorang tergantung pada aktivitas di mana orang tersebut terlibat) dan dengan sumber daya yang tersedia (sebuah tubuh yang sehat mengkonsumsi makanan yang sehat). Dengan demikian, kesehatan dipandang tidak hanya bergantung pada pilihan yang dibuat oleh individu, tetapi juga pada penataan lingkungan di mana orang tersebut tinggal.

\section{Status kesehatan - faktor institusional dan individu yang mempengaruhinya}

Secara umum, narapidana muda yang berpartisipasi dalam kelompok fokus menyatakan bahwa status kesehatan mereka memburuk selama dalam tahanan. Status kesehatan tergantung baik pada faktor individu maupun pada kondisi institusional. Dalam hal kondisi kelembagaan, menurut banyak alasan penurunan status kesehatan adalah: diletakkan oleh narapidana muda dalam kaitannya dengan lingkungan penjara, ditandai sebagai bermasalah. Mereka berbicara tentang sulitnya menjaga kebersihan kamar dan diri akibat berbagai penyakit kulit, sulit diberantas dan yang mencemari ruang hidup. Tahanan muda juga berbicara tentang tidak dapat mengakomodasi kebiasaan narapidana lain (seperti kebiasaan merokok) atau penyakit (seperti TB, hepatitis atau HIV). Secara umum, ruang penjara menampung banyak orang.

Dengan demikian, kebiasaan buruk dan/atau penyakit narapidana dipandang memiliki pengaruh langsung terhadap kesehatan orang lain. Aspek bermasalah lain dari lingkungan penjara adalah akses yang tidak tepat ke sumber daya yang menjaga hidup sehat selama dalam tahanan: air minum, air panas, pemanas, makanan sehat, udara segar di dalam ruangan, kegiatan olahraga teratur, perawatan medis yang cepat dan kualitatif, kontak keluarga.

Staf Lapas juga setuju bahwa status kesehatan narapidana muda sulit dipertahankan karena penataan dari unit-unit penjara. Narapidana muda dipandang memiliki kebutuhan khusus yang membutuhkan organisasi yang berbeda penjara dalam hal ruang dan staf. Misalnya, selain "kepadatan penjara" klasik (dan yang kami maksud adalah tingginya jumlah narapidana per meter persegi) yang menjadi ciri sebagian besar unit penahanan, jenis "kepadatan" lainnya juga muncul - tingginya jumlah narapidana per jumlah staf penjara dan per luar ruangan ruang angkasa. Karena fakta bahwa unit detensi tidak memiliki staf yang cukup untuk mengawasi tahanan saat berada di luar penjara ruang dan fakta bahwa ruang sosial (di dalam institusi dan di 
luar ruangan) tidak mencukupi jika dibandingkan dengan jumlah narapidana, narapidana muda menghabiskan sebagian besar waktu di dalam kamar. Tapi, situasi ini tidak bisa digeneralisasikan ke semua unit tahanan di Indonesia. Masalah-masalah ini tidak khusus untuk pusat pendidikan ulang untuk anak di bawah umur, karena mereka diatur secara berbeda, seperti yang diamati saat di lapangan. Sebagian besar masalah yang dijelaskan sebelumnya adalah ditemukan di penjara untuk orang dewasa yang memiliki sayap menampung anak di bawah umur dan remaja dan penjara untuk anak di bawah umur dan remaja.

Terlepas dari semua kesulitan institusional yang mempengaruhi status kesehatan yang dirasakan, ada tahanan muda yang mengakui kesehatan mereka juga tergantung pada tingkat tertentu pada pilihan masing - masing . Bagi mereka, kesehatan datang pertama - bersih dan tetap bersih, hormati orang lain agar dihormati, makan makanan sehat sebanyak mungkin, dapatkan di luar rumah. Tapi cara berpikir dan bertindak ini marginal di penjara Indonesia. Untuk sebagian besar anak muda narapidana, pendidikan kesehatan mereka yang buruk sebelumnya tidak ditingkatkan selama dalam tahanan, kebiasaan buruk mereka sebelumnya adalah terus dilatih dan subbudaya penjara dan tekanan teman sebaya menjadi sangat penting ketika membuat halhal yang berhubungan dengan kesehatan pilihan. Misalnya, alasan di balik cara anggaran dibelanjakan lebih terkait dengan pemeliharaan posisi dalam hirarki sosial narapidana, daripada pemeliharaan gaya hidup sehat.

Staf penjara mengkonfirmasi fakta bahwa penurunan kesehatan tahanan muda juga terkait dengan pilihan dibuat secara individual. Namun, analisis yang lebih dalam menunjukkan bahwa bagian dari apa yang disebut "pilihan individu" ini dipengaruhi oleh tingkat tertentu oleh faktor eksternal seperti budaya penjara, tekanan teman sebaya, sejarah pribadi dan koneksi yang dipertahankan dengan dunia luar. Faktanya, pilihan narapidana muda dibatasi oleh kendala eksternal, sementara setiap hari keputusan yang secara negatif mempengaruhi status kesehatan mereka lebih mudah diambil dibandingkan dengan keputusan yang mempromosikan sebuah gaya hidup sehat. Dan ini bahkan lebih berlaku untuk kategori narapidana ini, karena usia mereka. Tahanan muda mengambil kesehatan begitu saja, karena mereka berada di awal perjalanan hidup mereka dan penyakit dikaitkan dengan usia tua.

Aspek yang dijelaskan oleh narapidana muda dalam kelompok fokus sejalan dengan data dari kuesioner. Narapidana muda yang sadar akan risiko kesehatan yang mereka hadapi selama dalam tahanan juga sadar aspek yang dapat membantu mereka merasa lebih sehat. Yang terpenting bagi mereka adalah: menjaga koneksi dengan keluarga dan kunjungan berkualitas $(30 \%)$, lebih banyak kegiatan di luar ruang lapas, baik di dalam lembaga maupun di luar rumah (24\%), makanan dan kondisi hidup yang lebih baik di dalam ruang penjara (16\%), layanan medis berkualitas (11\%) dll.

\section{Ketersediaan, kepentingan, metode penyampaian dan cakupan kegiatan promosi kesehatan}

Mengenai ketersediaan kegiatan promosi kesehatan, staf penjara menunjukkan bahwa area yang diselidiki oleh penelitian dicakup secara berbeda. Dari 41 kuesioner yang diisi, skor tertinggi terdaftar untuk penggunaan tembakau (38), HIV (38) dan pencegahan hepatitis (37), penggunaan alkohol dan obatobatan terlarang (36), penyakit menular seksual penyakit (36) dan tuberkulosis (35). Pada saat yang sama, staf penjara menganggap sangat penting semua yang diselidiki kegiatan promosi kesehatan (dalam skala 5, semua kegiatan mendapat nilai di atas 4,5). Jadi, ada perbedaan antara apa staf penjara menganggap diinginkan dan apa yang terjadi dalam kenyataan, yang berarti bahwa terlepas dari kenyataan bahwa semua kesehatan isu-isu yang dianggap penting, tidak cukup tercakup oleh kegiatan promosi kesehatan. Paling sedikit tersedia kegiatan promosi kesehatan di bidang praktik seks yang lebih aman dan penggunaan kondom (28) mengatasi tahanan dan karir kriminal (28), praktik yang aman untuk menyuntikkan narkoba (27), perubahan tubuh (26), mengatasi bullying (26), aman praktik tato dan tindik (24) atau kontrasepsi (19).

Metode penyampaian promosi kesehatan yang paling banyak digunakan adalah sesi 
kelompok (rata-rata 26 disebutkan) dan individu konseling (rata-rata 20). Pembatasan dana memaksa unit-unit tahanan untuk menggunakan sumber daya yang secara teratur tersedia, artinya staf lapas, meskipun jumlahnya terlalu kecil dibandingkan dengan yang dibutuhkan. Selebaran, poster dan brosur digunakan jika tersedia dari sumber eksternal. Juga, terlepas dari kenyataan bahwa pendidikan sebaya terlihat sebagai metode yang baik, sebenarnya metode ini paling sedikit digunakan (rata-rata 4,6) karena kesulitan dalam penerapannya.

Cakupan terbaik dengan kegiatan promosi kesehatan adalah pada isu-isu seperti tuberkulosis (rata-rata 24,6), HIV (rata-rata 24,6), penggunaan obat obatan terlarang (rata-rata 22,1), penyakit menular seksual (rata-rata 19,3), praktik seks yang aman dan penggunaan kondom (rata-rata 17,8 ), merokok (rata-rata 17,5) dan hepatitis (rata-rata 16,6). Hal ini sebagian besar disebabkan oleh fakta bahwa kegiatan tersebut didekati oleh administrasi penjara dalam kemitraan dengan aktor lain (internasional) organisme, lembaga dari sektor publik dan organisasi non-pemerintah) dan program yang berbeda yang telah diterapkan dalam beberapa dekade terakhir.

\section{Kesesuaian dan disparitas dalam kegiatan promosi kesehatan}

Tampaknya ada kesesuaian tertentu antara kebutuhan narapidana muda untuk mengetahui lebih banyak tentang masalah kesehatan yang berbeda dan pentingnya mereka memberikan aspek-aspek ini. Secara umum, narapidana muda ingin tahu lebih banyak tentang masalah kesehatan yang penting bagi mereka. Juga, narapidana muda menyadari pentingnya semua masalah kesehatan yang diteliti.

Tapi, ketika membandingkan data yang dikumpulkan dari narapidana muda dengan yang dari staf penjara, perbedaan dapat terlihat. Isu kesehatan yang ingin diketahui oleh narapidana muda tentang gizi sehat (90\%), kebersihan gigi/mulut (86\%), menyalin dengan tahanan dan karir kriminal $(84 \%)$, menghentikan karir kriminal $(82 \%)$, mengelola konflik (75\%) dan menyalin dengan bullying (74\%). Tetapi daerah-daerah ini tidak cukup tercakup oleh unit-unit penahanan melalui kesehatan kegiatan promosi. Satu penjelasan terletak pada kenyataan bahwa unit-unit penahanan biasanya berfokus pada aspek-aspek yang bersangkutan pengelolaan populasi penjara yang besar. Pada saat yang sama, dukungan eksternal datang dari yang berbeda lembaga dan organisasi menekankan pada isu-isu yang menempati agenda publik, yang berarti HIV, PMS dan TB pencegahan, penggunaan narkoba dan tembakau. Jadi, meskipun jelas bahwa tahanan muda memberikan arti penting pada area-area yang mempengaruhi kehidupan sehari-hari dan masa depan mereka, hal ini kurang diperhatikan oleh administrasi penjara karena kebutuhan untuk mengelola risiko yang terkait dengan pengawasan populasi besar. Pada saat yang sama, kita juga harus mengatakan itu narapidana muda cenderung segan untuk berbicara tentang masalah kesehatan yang menyangkut kehidupan seksual, penggunaan ilegal narkoba, tato, tindik dan melukai diri sendiri, ini adalah tindakan terlarang pada umumnya. Dengan demikian, larangan perilaku tercermin dalam wacana mereka juga. Ini tidak berarti bahwa narapidana muda tidak melakukan hubungan seksual dengan narapidana lain selama di penjara, tidak menggunakan narkoba dan menato diri, tidak menusuk atau melukai diri sendiri selama dalam tahanan. Faktanya, narapidana muda jarang mengalami pengalaman seperti itu

\section{Merasa Lebih Sehat Dalam Tahanan - Pilihan Pribadi, Kerentanan dan Kendala Lingkungan}

Narapidana muda merasa lebih sehat ketika mereka menerima dukungan emosional dan material dari keluarga mereka. Faktor ini mendapat nilai tertinggi (30\%). Sebagai faktor individu, dukungan keluarga tersedia jika hubungan terjalin dan stabil. Namun, faktor ini juga dapat dipengaruhi secara kelembagaan. Misalnya, dalam kasus tahanan wanita, unit tahanan sedikit dan terkadang terletak jauh dari tempat tinggal keluarga. Ini membuat kunjungan menjadi sulit, terutama jika keluarga dihadapkan pada kesulitan keuangan. Persamaan yang sama berlaku untuk aspek lain yang diidentifikasi oleh narapidana. Sedang mengerjakan olahraga atau kegiatan di luar ruangan (24\%) dapat dilihat sebagai masalah 
keinginan pribadi, tetapi meskipun keinginan itu ada, hal itu dapat kadang-kadang sulit untuk mengakses layanan tersebut karena fakta bahwa, secara umum, unit tahanan mengajukan besar populasi dan memiliki sedikit ruang di mana kegiatan tersebut dapat disediakan. Soal makanan (16\%), memang benar bahwa narapidana muda cenderung membuat pilihan yang tidak sehat saat berbelanja, tetapi ada juga keluhan tentang kualitas makanan tiga kali sehari yang disediakan oleh administrasi penjara. Menjaga kebersihan kamar (16\%) dan pribadi kebersihan (12\%) juga tergantung pada gaya hidup narapidana dan tingkat kekayaan mereka, tetapi kebersihan juga sulit untuk dijaga kamar yang menampung banyak orang dan jika air panas tidak tersedia setiap hari karena keterbatasan kelembagaan sumber daya. Pembatasan anggaran yang dihadapi unit-unit tahanan juga mencerminkan kualitas pelayanan medis (11\%). Meskipun infrastruktur jaringan medis ada, masalah utama yang terus-menerus adalah defisit staf medis yang tinggi. Selain itu, kendala kelembagaan lainnya adalah kurangnya spesialis, kurangnya program pelatihan berkelanjutan untuk staf medis, dana yang tidak mencukupi untuk peralatan fasilitas medis dan akses narapidana yang buruk ke jaringan perawatan medis komunitas. Ini faktor kelembagaan memiliki dampak langsung pada kesehatan narapidana dan persepsinya. Tahanan muda juga mengidentifikasi aspek-aspek lain yang dapat berkontribusi pada peningkatan perasaan sehat mereka selama dalam tahanan: memelihara hubungan baik dengan narapidana lain (7\%), partisipasi dalam kegiatan sosial budaya (6\%), lebih banyak kebebasan untuk melakukan kegiatan hukum yang berbeda (5\%), tidak adanya obatobatan terlarang, alkohol dan tembakau di penjara (4\%) dan bekerja (2\%).

Seperti disebutkan sebelumnya, semua aspek ini memiliki keunggulan ganda. Kegiatan promosi kesehatan penting untuk meningkatkan basis pengetahuan tahanan dalam apa yang menyangkut pilihan pribadi mereka. Mereka dimaksudkan untuk memungkinkan muda narapidana untuk membuat keputusan yang tepat dalam hal bertindak dengan cara yang sehat atau tidak sehat. Tapi untuk ini kegiatan untuk memiliki efek tertinggi, unit penahanan perlu menyediakan ruang, sarana, dan manusia yang diperlukan mendukung. Isu-isu memastikan lingkungan penjara yang sehat dan melaksanakan kegiatan promosi kesehatan lebih lanjut berlaku terlebih lagi dalam kasus narapidana muda, yang dianggap oleh staf penjara sebagai kelompok yang rentan. Anak-anak dan pemuda di awal kehidupan mereka dan tidak memiliki pengalaman yang diperlukan dalam mengambil keputusan yang tepat di apa yang menyangkut status kesehatan mereka saat ini dan masa depan. Mereka juga rentan terhadap paparan pengaruh yang berbeda. Lainnya kategori kelompok rentan diidentifikasi oleh staf penjara untuk menerima pelayanan promosi kesehatan khusus yang pengguna narkoba, perempuan, etnis minoritas, tahanan disalahgunakan, migran, sakit kronis, tua dan tahanan sakit mental. Ini kategori memiliki kebutuhan medis, emosional dan sosial tertentu yang membuat mereka tunduk pada masalah kesehatan lebih lanjut.

\section{Hambatan utama dalam melaksanakan kegiatan promosi kesehatan}

Faktor institusional paling umum yang mempengaruhi sistem penjara Rumania secara keseluruhan adalah kekurangan staf dan dana. Seperti disebutkan dalam 2010 laporan administrasi penjara, "hunian pekerjaan adalah sekitar $79 \%$ dari total 15.500 pekerjaan yang disediakan". Laporan yang sama juga menyebutkan bahwa "kesulitan utama yang melekat untuk jaminan hak atas perawatan kesehatan adalah kekurangan staf medis dengan studi tinggi dan menengah. Untuk penjara populasi sekitar 28.244 tahanan, perawatan kesehatan disediakan oleh total 777 staf medis. Sama Situasi ini berlaku untuk staf yang bergerak di sektor psiko-sosio-pendidikan, di mana sejumlah 650 orang bekerja, dalam kategori ini termasuk pekerja sosial, psikolog, pendidik dan lainnya profesional dengan tanggung jawab dalam pelaksanaan program psikososio-pendidikan. Dalam hal apa? kendala anggaran, laporan yang disebutkan sebelumnya menyatakan bahwa anggaran lembaga menurun sebesar 6\% dalam 2010 untuk 2009, bab yang paling terpengaruh 
menjadi orang mengenai barang dan jasa. Ini kekurangan tercermin dalam wawancara.

Faktor lain yang menjadi penghambat dalam pelaksanaan promosi kesehatan yang efektif adalah kurangnya koherensi antara staf penjara. Salah satu saran yang dibuat oleh psikolog penjara yang berpengalaman adalah bahwa kaum muda belajar lebih baik dengan mengikuti model daripada berpartisipasi dalam berbagai jenis pelajaran yang kurang lebih bersifat teoretis alam. Dalam praktiknya, program yang mempromosikan perilaku sehat dilaksanakan oleh staf khusus (medis atau psiko-sosialpendidikan). Agar program-program ini efektif, staf penjara lainnya datang ke kontak dengan tahanan muda harus mempromosikan prinsip-prinsip yang sama dalam perilaku mereka sendiri, karena mereka juga agen sosialisasi. Jika kita melihat penjara sebagai institusi total, di mana narapidana dipaksa untuk berbagi ruang bersama untuk periode waktu yang berbeda, penting untuk memahami bahwa setiap salah satu staf penjara, sebagai individu, menjadi bertanggung jawab dengan mempromosikan cara-cara yang sehat perilaku. Hal ini juga penting bahwa tahanan, baik itu dr daftar atau sebagai kalimat, tidak mempengaruhi kesehatan tahanan sebagai konsekuensi dari kekurangan institusional. Dimana seperti kekurangan yang ada, mereka harus diakui dan diselesaikan untuk memberikan dasar yang diperlukan untuk pelaksanaan promosi kesehatan selanjutnya.

Dalam hal apa faktor-faktor yang berkaitan dengan narapidana, salah satu yang menghambat pelaksanaan beberapa kesehatan? program promosi yang saat ini tersedia di unit tahanan Rumania adalah tingkat pendidikan rendah dari tahanan muda - Menurut data yang termasuk dalam laporan administrasi penjara 2010, 8,6\% (sebesar 2.421 tahanan) dari total populasi penjara menghadiri sekolah, dari yang $43 \%$ (sebesar 1.034 tahanan) menghadiri di tingkat primer (ANP 2010, 52-53). Data mengenai kelompok usia 14-24 tahun tidak tersedia, namun penting perlu diperhatikan tingginya persentase narapidana yang bersekolah di sekolah dasar dari populasi umum yang bersekolah. Artinya dalam semua kelompok umur terdapat narapidana dengan kebutuhan pendidikan dasar. Dan aman untuk menegaskan bahwa persentase riil narapidana dengan tingkat pendidikan rendah bahkan lebih tinggi, seperti yang ditunjukkan oleh indikator di atas hanya data tentang narapidana yang mewujudkan keinginannya mengenyam pendidikan dengan bersekolah. Ini Penegasan ini sejalan dengan pernyataan yang dibuat oleh staf penjara: banyak narapidana muda tidak memiliki pendidikan minimum, yang pada gilirannya menghambat pelaksanaan berbagai program dan penyediaan layanan.

Faktor individu lain yang bertindak seperti hambatan untuk promosi perilaku sehat yang efektif adalah narapidana muda. minat umum yang rendah mengenai masalah kesehatan, kurangnya kerja sama mereka dengan staf penjara dan prioritas mereka yang berbeda. Untuk batas tertentu, tahanan muda bunga rendah pada masalah kesehatan dimengerti. Seperti disebutkan sebelumnya, remaja pada umumnya memiliki keyakinan bahwa mereka aman dari risiko sakit karena usia mereka yang masih muda. Dengan demikian, mereka kurang tertarik pada halhal yang menyangkut perspektif penyakit atau risiko yang ditimbulkan oleh perilaku tidak sehat dan keputusan hidup. Untuk ini kami menambahkan keengganan umum mereka terhadap permintaan, rekomendasi, dan saran staf penjara dan prioritas mereka yang berbeda dalam mengambil keputusan yang sehat, yang keduanya dihasilkan oleh tekanan hidup di penjara. partisipasi tulus untuk program penjara sulit untuk dicapai. Secara umum, kita bisa baik berbicara tentang non-partisipasi (artinya tahanan tidak mendaftar dalam program penjara) atau partisipasi formal (artinya narapidana mendaftar ke program, tetapi tidak memperhatikan, mengganggu kegiatan atau hanya menunjukkan minat ketika mereka menerima insentif). Ini dapat dilihat sebagai bentuk perlawanan, fakta yang juga dapat dipahami oleh sebuah sampai batas tertentu, karena tahanan sebenarnya dapat dianggap sebagai tipe khusus "klien paksa". Kerja sama narapidana dapat diperoleh dengan pergeseran perspektif. Mereka bisa menjadi "klien sukarela" ketika lingkungan terasa aman cukup terbuka, emosi dan reaksi mereka diakui, komunikasinya lugas dan otentik dan alasan penolakan mereka diidentifikasi dan dipertimbangkan 


\section{Saran untuk peningkatan kegiatan promosi kesehatan}

Setelah diketahui semua faktor ini yang bertindak sebagai hambatan dalam pelaksanaan program promosi kesehatan untuk anak muda tahanan, serangkaian saran untuk perbaikan menjadi lebih jelas. Yang pertama dan paling penting dari kekhawatiran mereka manajemen staf penjara, dan lebih khusus lagi: menyelenggarakan pelatihan awal dan berkelanjutan agar staf mendapatkan berspesialisasi dalam bekerja dengan tahanan muda, mempekerjakan lebih banyak staf untuk mencakup semua sektor penjara dan menggunakan pengawasan dalam proses rekrutmen sehingga dapat merekrut yang terbaik dari yang terbaik. Saran lain terkait perluasan kerja sama dengan faktor luar yang dapat memberikan dukungan dalam hal ini dan mengembangkan program promosi kesehatan khusus untuk tahanan muda. Satu rekomendasi khusus dengan implikasi besar dalam pengembangan kesehatan yang efektif peralatan promosi menyangkut metode penyampaian. Beberapa prinsip harus dipertimbangkan ketika memilih dan / atau mengembangkan metode untuk menyampaikan program-program yang menargetkan tahanan muda. Metode-metode ini harus mempekerjakan kreativitas narapidana muda dan meningkatkan keterampilan komunikasi mereka, membuat koneksi dengan kehidupan nyata sehingga memperkuat hasil pembelajaran, menggunakan teknologi di mana dan kapan diizinkan atau dianggap tepat, dan terakhir namun tidak kalah pentingnya menciptakan peluang untuk berkembang, memelihara dan memperoleh manfaat dari dukungan masyarakat.

\section{PENUTUP}

Hasil ini harus dianggap sebagai dasar untuk pengembangan perangkat promosi kesehatan yang efektif. Beberapa prinsipprinsip harus dipertimbangkan ketika merancang peralatan tersebut. Seharusnya mudah digunakan oleh yang berbeda jenis profesional, baik oleh petugas lapas maupun mitra dari masyarakat. Itu juga harus mudah digunakan oleh anak muda narapidana, mengingat tingkat pendidikan mereka umumnya rendah. Proses pembelajaran harus difasilitasi dengan metode yang mendorong keterampilan komunikasi dan kreativitas narapidana muda. Dengan demikian, latihan harus dibangun sedemikian rupa sebagai koneksi dengan kehidupan nyata yang mudah dibuat. Jika sumber daya tersedia dan dianggap tepat, teknologi harus digunakan. Dan yang tak kalah pentingnya, peralatan ini harus mencakup instruksi untuk implementasinya, keterampilan yang dibutuhkan untuk bekerja dengan tahanan muda. Ini juga dapat terdiri dari paket kecil untuk melatih staf. Peralatan yang dihasilkan oleh proyek HPYP menggabungkan prinsipprinsip ini dan tersedia dalam format elektronik siap pakai.

\section{DAFTAR PUSTAKA}

ANA. (2009). Laporan Nasional tentang situasi obat. Indonesia: Evolusi baru.

Hardywinoto, \&. S. (2002). Anak Unggulan Berotak Prima. Jakarta: Gramedia .

Herdiansyah.H. (2012). Metode Penelitian Kualitatif: Untuk IImu-IImu Sosial. Jakarta: Salemba Humanika. .

Hurlock, E. (1999). Psikologi Perkembangan: Suatu Pendekatan Sepanjang Ruang kehidupan. Edisi 5. Jakarta: Erlangga.

Kartono.K. (2002). Patologi Sosiak 2 Kenakalan Remaja. Jakarta: Raja Grafindo Persada. .

Kartono.K. (2014). Patologi Sosial, Jilid 1. Jakarta: Rajawali Press. .

Kartono.K. (2014). Patologi Sosial, Jilid 1. Jakarta: Rajawali Press. .

Lestari.S. (2012). Psikologi Keluarga: Penanaman Nilai dan Penanganan dalam Keluarga Edisi Pertama. Jakarta: Kencana Prenadamedia Group.

Maria.U. (2007). Peran Persepsi Keluarga dan Konsep Diri Terhadap Kecenderungan Kenakalan Remaja. Yogyakarta: Tesis Psikologi Universitas Gajah Mada.

Moeljatno. (2008). Asas-Asas Hukum Pidana. Jakarta: Rineka Cipta.

Moshman.D. (2005).

Adolescent Psychological Development: Rationality, Morality, and Identity. 
New Jersey: Lawrence Erlbaum Associates.

Naim.A, S. C. (2015). Profil Anak Indonesia 2015. Jakarta: Kementerian Pemberdayaan Perempuan dan Perlindungan Anak (KPP\&PA).

Nelfice, E. \&. (2014). Hubungan Dukungan Keluarga Dan Harga Diri Remaja di Lembaga Pemasyarakatan. Jurnal Ilmu Keperawatan Universitas Riau.

Omboto, J. O. (2013). Factors Influencing Youth Crime And Juvenile. International Journal Of Research In Sosial Science.

Papalia, D. E. (2011). Human Development, Bagian V-XI. Jakarta: Kencana.

Pratiwi.A. (2016). Pembinaan Narapidana Remaja Di Lembaga Pemasyarakatan ( Studi Lembaga Pemasyarakatan Kelas IIA Kota Metro. Lampung: Skripsi Fakultas Hukum Universitas Lampung.

Rochmawati.D. (2014). Hubungan Antara Konsep Diri dan Kemampuan Memaknai Hidup pada Narapidana Remaja Di Lembaga Pemasyarakatan Kelas I Semarang . Semarang: Jurnal Ilmu Keperawatan Universitas Islam Sultan Agung Semarang.

Rumadan, Ismail. "Problem Lembaga Pemasyarakatan di Indonesia dan Reorientasi Tujuan Pemidanaan." Jurnal Hukum dan Peradilan 2.2 (2013): 263-276. DOI: http://dx.doi.org/10.25216/jhp.2 $.2 .2013 .263-276$

Santrock, .. (2012). Life-Span Development Perkembangan Masa Hidup. Edisi 13. New York: McGraw-Hill.

Santrock.J.W. (2007). Remaja. Edisi 11. Jakarta: Erlangga.

Sarwono.S.W. (2010). Psikologi Remaja. Jakarta: PT. Grafindo Persada. .

Sarwono.S.W. (2010). Psikologi Sosial: Individu dan Teori Sosial. Jakarta: Rajawali. .

Savitri.A, \&. U. (2012). Faktor-Faktor yang Menyebabkan Kenakalan Remaja pada Anak Didik Lapas Anak Kutoarjo - Semarang: Jurnal Fakultas Psikologi Unissula Semarang.
Sholichatun.Y. (2011). Stress dan strategi koping pada anak didik di Lembaga Pemasyarakatan Anak. Malang: Jurnal Psikologi UIN Malang.

Sunaryanti.S.S. (2016). Relationship The Parenting Pattern And The Juvenile Delinquency At State Senior Secondary School 8 Surakarta. Surakarta: Indonesian Journal On Medical Science.

Szabo, A. (2010). Promosi kesehatan untuk narapidana muda. Indonesia: Tinjauan Literatur Nasional.

Petrus Irwan Panjaitan dan Pandapotan Simorangkir, Lembaga Pemasyarakatan Dalam Prespektif Sistem Peradilan Pidana Penjara, ( Jakarta : Pustaka Sinar Harapan, 1995)

T.P.Handayani. (2010). Kesejahteraan Psikologis Narapidana Remaja di Lembaga Pemasyaratakan Anak. Semarang: Fakultas Psikologi Universitas Diponegoro. 